Oxford in 1938, and played a leading part in radar research and development during the Second World War. After the War, he was engaged in fundamental nuclear physics research at Chalk River in Canada and at Harwell, and was later in charge at Ferranti, Ltd., of development and design of the guidance and eontrol system of the guided weapon now known as Bloodhound. In 1954 he joined the then British Electricity Authority with responsibility for the design, construction and operation of nuclear power stations, and is at present chief research and development officer of the Central Electricity Generating Board.

Mr. Dennis Hennessey has been appointed by the Corporation to a new post of deputy managing director. Mr. Hennessey, who was a former principal patents officer at the Ministry of Supply, joined the staff of the Corporation in 1950 at the age of thirtyeight and was made an executive member of the Corporation in 1956.

\section{Government Research on Food Preservation}

THREE research stations of the Department of Scientific and Industrial Research, all concerned with the preservation, storage, handling or protection of foodstuffs, will be transferred to the Agricultural Research Council on July 1. They are the Ditton Laboratory at Larkfield, Kent, the Low Temperature Research Station at Cambridge, and the Pest Infestation Laboratory at Slough. The agreement between the Council for Scientific and Industrial Research and the Agricultural Research Council-announced in the House of Lords by the Lord President of the Council, Lord Hailsham, on March 4-was made because the itwo Councils consider that Government research on food other than fish would be more effectively pursued under one authority. The staff in the three laboratories, numbering about 200 , will be invited to transfer to the service of the Agricultural Research Council.

Agriculture at Aberdeen : Prof. J. R. Raeburn

DR. J. R. RAEBURN, recently nominated to the Strathcona-Fordyce Chair of Agriculture at Aberdeen, in succession to Prof. A. B. Stewart, who has been appointed director of the Macaulay Institute for Soil Research (see Nature, 181, 1105 ; 1958), was educated at Manchester Grammar School, at the University of Edinburgh and at Cornell University. His career has been one of widely varied experience in research. teaching and administration. He did practical farm work in Scotland during 1928-29, and was engaged in research at the Edinburgh Animal Breeding Research Institute during 1932-33, before proceeding to his doctorate at Cornell. During 1936-37 he had the unusual experience of serving at the University of Nanking under Prof. Buck, whase collection of information on the subsistence agriculture of Chinese peasants is unsurpassed in any other such country. The agriculture of African and Asian peasants has been one of Dr. Raeburn's principal fields of research and teaching during his tenure of the readership in agricultural economies in the University of London since 1949. He has travelled extensively and has been much consulted by the Colonial Office on the development of its agricultural policy. During the Second World War he served in the Ministry of Food as secretary of the Home Agricultural Supplies Committee, the duty of which was to plan the develop. ment of home supplies in such a way as to give the maximum release of shipping space. During 1938-39 and 1946-49 he was a research officer at the Oxford Agricultural Economics Research Institute. At an early age Dr. Raeburn was recognized as an outstanding figure in his own fields of research. His work combines extensive knowledge and experience with subtle and sympathetic understanding of the difficult problems of decision which every farmer has to face, and strong criticism of some unreliable methods of sampling used in obtaining agricultural economic information.

\section{The Jodrell Bank Radio Telescope}

IN replying on an adjournment debate in the House of Commons on March 4, in which Mr. R. E. Winterbottom and Lt.-Col. W. H. Bromley-Davenport had, while supporting the Committee of Public Accounts, pleaded for a more generous attitude from the Government in meeting the outstanding $£ 140,000$ on the Jodrell Bank Radio telescope, Mr. H. Nicholls defended the Government's attitude and, outlining the financial history in some detail, claimed that the Government from the first had given all the help it possibly could, within the limits of sound financial control, to this great project. Out of eight recent major university schemes costing more than $£ 100,000$ each which are being supported by the Department of Scientifie and Industrial Research, three, including the Jodrell Bank project, had come under the ægis of the University of Manchester, and Mr. Nicholls dirl not think that the University had been treated ungenerously. The Government did not want to discourage the universities and scientists from embarking on similar projects which would place Britain in the lead in the future, but it must know on what the money was being spent before it was granted. It must also respect a second principle, that if the cost of any project is liable to be greatly increased, the Government department concerned must be kept, clearly informed from start to finish and should agree to the extra expenditure before being held liable for it. Mr. Nicholls promised to report to the Lord President what was said in the House.

\section{Transient Reactor Test Facility achieves Criticality}

ThE Transient Reactor Test Facility (Treat). a reactor designed to investigate the effect of extreme nuclear heat upon fast reactor fuel elements, achieved criticality at 23.30 E.D.T. on February 23 at the U.S. Atomic Energy Cormmission's National Reactor Testing Station, Idaho Falls, Idaho. The reactor, designed by the Argonne National Laboratory, can deliver a high-intensity, short-duration surge of nuclear energy without damage to the facility itself. The surge will result when a large number of atoms undergo fission in a short time and will cause intense heat to be generated in the sample being tested. The surge will be useful in simulating abnormal reactor operating conditions and will permit reactor designers to observe on a small scale the effect of such conditions on prototype fuel elements planned for fast, reactors. The facility, which resembles a research reactor, is fuelled with uranium oxide uniformly dispersed in graphite. The graphite lsows down the neutrons produced by the fission of uranium atoms, enabling the neutrons to collide with other uranium atoms to continue the chain reaction. During the surge, the abnormal amount of heat generated in the fuel due to fission is transferred instantaneously to the graphite, which absorbs the released energy. As the graphite becomes heated, its efficiency in slowing down the neutrons decreases. Consequently fewer 